\title{
D-15 TERTIARY CARBONATE PLATFORMS DEVELOPMENT IN NORTH EAST OFFSHORE TUNISIA
}

ABDERRAZAK BELHAIZA and FRAJ HARROUDA

ETAP, 27 bis Avenue Khereddine Pachaa, 1002 Tunis, Tunisia

The study area lies on north east offshore Tunisia and interests the Gulf of Hammamet, the Cap Bon peninsula and the Gulf of Tunis. Geologically the area enrolled several carbonate platforms during Tertiary time.

In the Lower Eocene a widespread open marine carbonate platform represented by a globigerina rich mudstone wackestone including pyrite aggregates and cherts. The thickness increases northward and southward around a central eroded high (Fig 2). Locally, reworked Ypresian Bou Dabbous has been recorded.

Fractured Bou Dabbous section flowed up to 20,000 BOPD in Belli\# 1 and recently more than 3000 BOPD, shared between 3 fractured zones, from Al Manzah\# 1(fig.1).

During the Middle-Late Eocene, a minor compressional phase, shown by the locally developed base Halk El Menzel unconformity in Tazarka\# 1 and Sbeitla\# 1 areas, took place. The general paleogeography of the study area was relatively similar to that of the Early Eocene. A shallow marine carbonate platform developed to the west of the uplifted central area (Halk El Menzel platform), while an equivalent deep marine shaly facies (Souar shale) developed to the east.

The carbonate section (Halk El Menzel formation) is represented by a white chalky mudstonewackestone, pyretic, glauconitic and rich in bivalves, bryozoans and corals indicating a shallow marine to inner neritic environment (Fig. 4). Post Eocene uplifting induced active dolomitization mostly in central Gulf of Hammamet. This section is conformably overlain by the OligoceneEarly Miocene (Ketatna formation) carbonates, the top seal of these carbonates may be absent except in some recent grabens where it may be sealed by Late Miocene-Pliocene shales.

Reservoir properties are good with porosity of about $25 \%$ and permeability as high as $700 \mathrm{md}$. To date only traces of dead oil have been encountered in Oudna\# 2 and Tazarka\# 3.

During the Late Oligocene-Early Miocene, major alpine compression $\left(\mathrm{N} 140^{\circ}\right)$ occurred and new areas were uplifted. The area of the Late Eocene central highs became elongated north and south. The uplift of these area could have started during the Early Oligocene, but reached a maximum during the Late Oligocene. Beige-brown wackestone-packstone, rich in fossil debris partially recristallized into slightly dolomitized microspar, developed to the west of the central NE-SW elongated paleohigh, represents the Late Oligocene-Early Miocene(Ketatna) limestone. The presence of Lepidocyclines and Coelenterites indicates a shallow marine upslope environment with local bioconstructions (Fig 4). This platform is ristricted to the SE of the Gulf of Hammamet and consists of a thick fractured carbonate ( $300 \mathrm{~m}$ in Halk EI Menzel area). Porosity of up to $30 \%$ was found in Halk El Menzel\# 1 associated with good permeability improved by the close spaced fracture system and diagenesis. The Late Langhian Mahmoud shales

EAGE Conference on Geology and Petroleum Geology - St. Julians, Malta, 1 - 4 October 2000 
constitutes a top seal. The Ketatna reservoir tested 2,200 BOPD in Halk El Menzel\#4.

After the Late Oligocene-Early Miocene orogeny, the transgression initiated in the Early Langhian led remotely to the flooding of most of the previous uplifted zones. This induced in the Early Langhian a new carbonate facies belt known as Ain Grab carbonate platform. The latter is represented by a brown packstone-grainstone, hard, sandy at the base, grading upward to shaly wackestone and grey-green shales. Three depositional environments have been identified:

i-The gypsiferous carbonate facies of the Cap-Bon peninsula, corresponding to an inner shelf environment (Fig 6).

ii-In the south, the limestone and the sandy limestone facies rich in benthonic forams, ostracods and pelecypods developed in a middle shelf environment. The sandy limestone facies deposited over the winnowed part of the shelf (facing towards the continent) and the limestone facies developed over the outer shelf (facing to the open sea) (Fig 6).

iii-To the north, the shaly limestone facies, rich in planctonic fauna which suggests an open sea shelf environment. The average thickness is about $40 \mathrm{~m}$. Recorded porosity values vary from 10 to $21 \%$. Permeability ranges from 0.2 to $100 \mathrm{md}$. Yasmin\# 2 well tested 3295 BOPD from this limestone(Fig 6). Top seal is provided by a thick Late Langhian (Mahmoud) shale section.

After the Langhian transgression, a limited regression started in the Serrvallian and continued during the Tortonian. A N $140^{\circ}$ compressional phase occurred in the Late Tortonian. The study area experienced local tectonic inversions, such as the eastern edge of the Gulf of Hammamet, the southern half of the Cap Bon peninsula and the southern part of the Gulf of Tunis.

The previously uplifted eastern part of the Gulf of Hammamet and particularly areas of Mactaris\# 1, Oudna and Carthage\#1 wells continue to shallow up. They experienced gypsum deposits indicative of a lagoonal environment, with a gypsiferous restricted carbonate platform towards the north and the east and an open carbonate platform towards the south (Fig 7).

Please note that this abstract has been retyped and the figures are scanned, as it was not received in a digital format. EAGE cannot be held responsible for any typing errors that may occur nor for any results that might arise from scanning the figures in this text. 


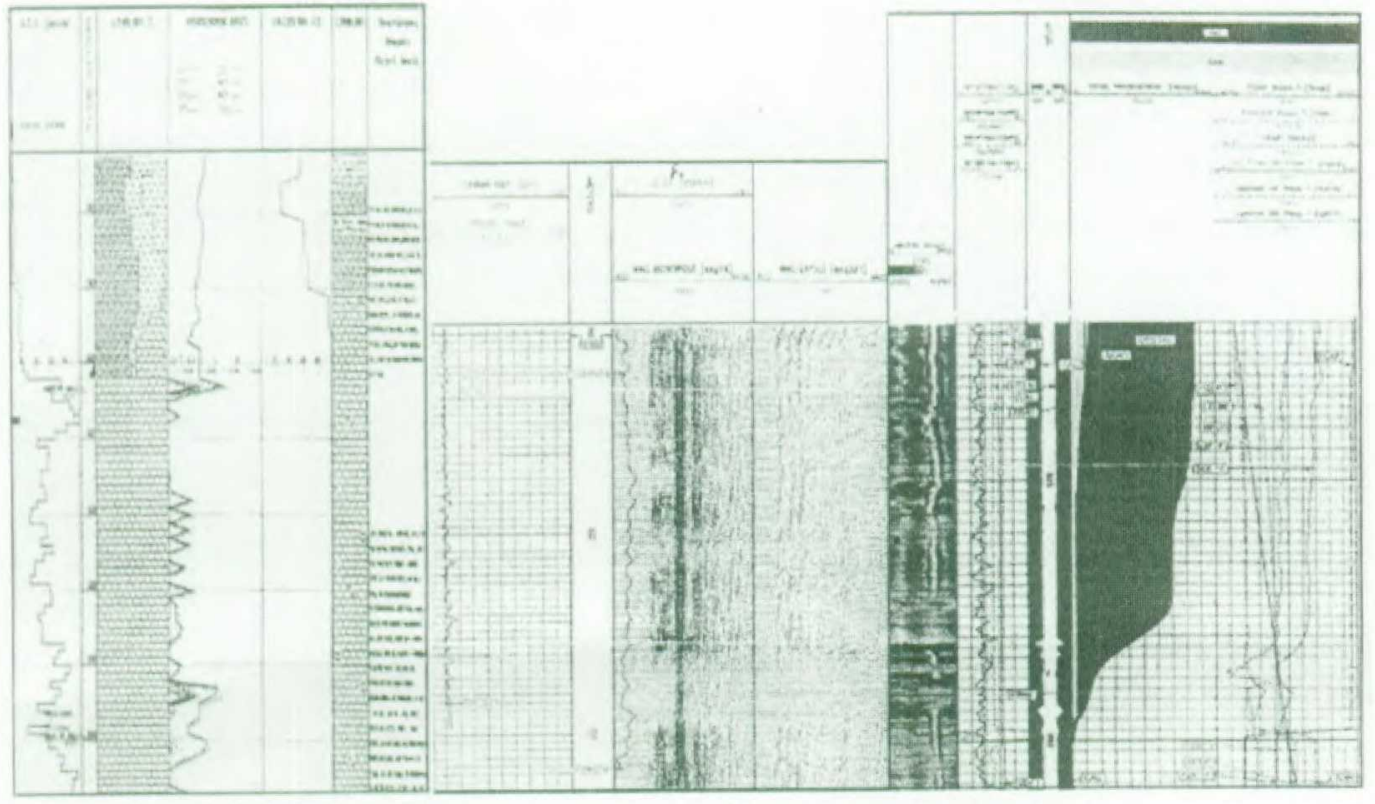

ig.

ertical Fracture Sets Destruhutio
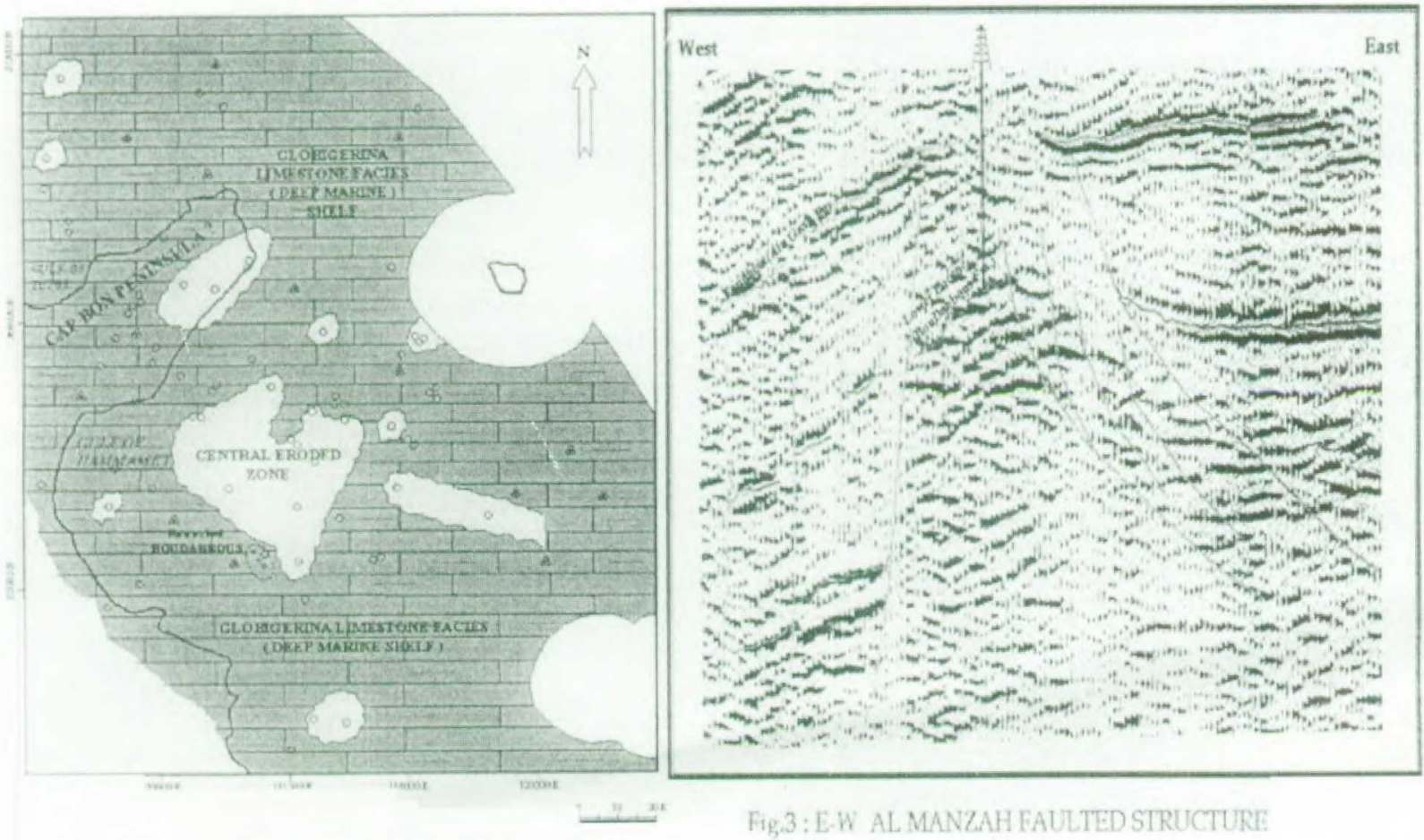

H1. 2: LOWYR ENE FACIES MAP (BOU DABBOUS $\mathrm{M}$.) 
粘
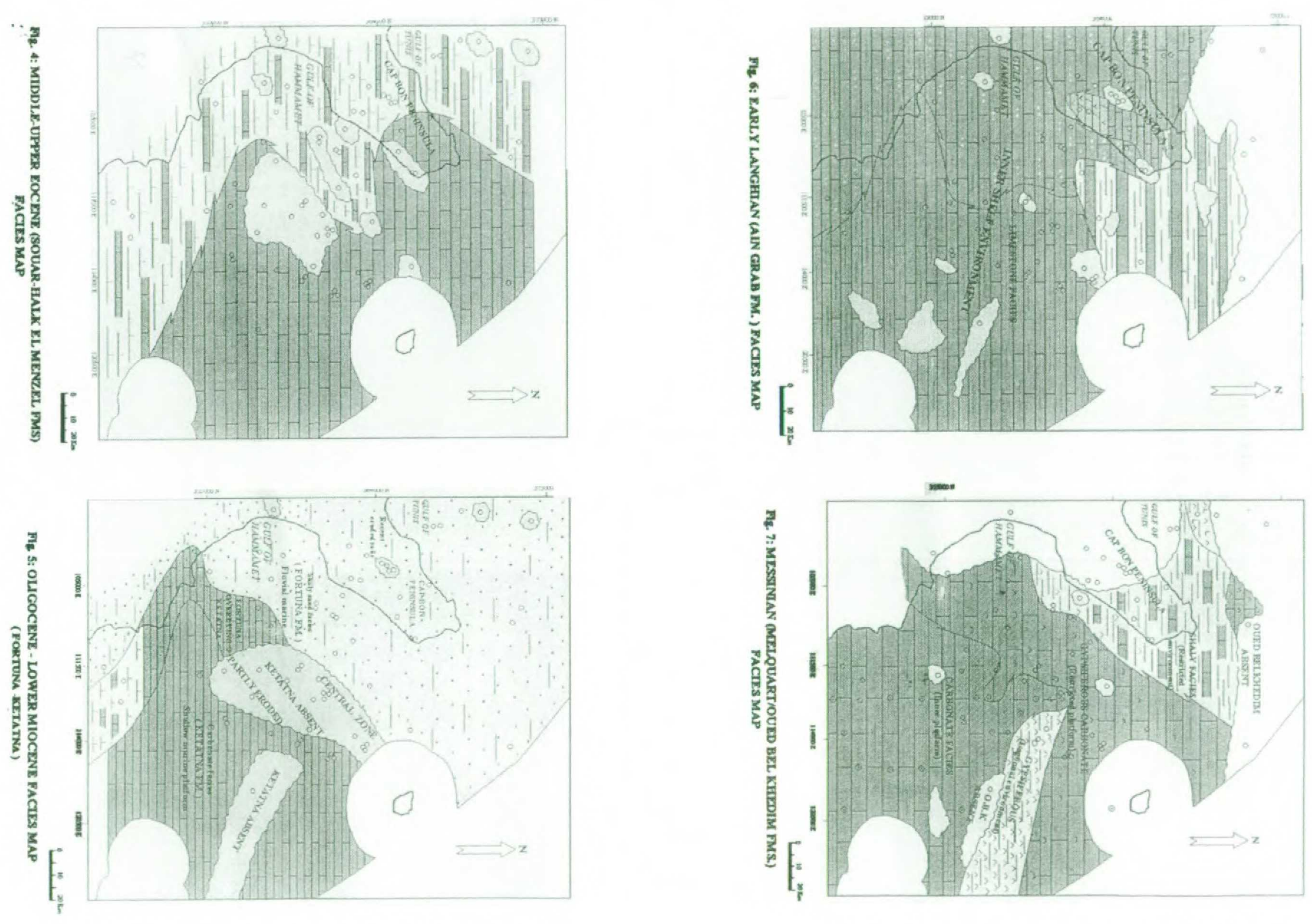